\title{
Foreign Exchange and the Capital Market Dynamics: New Evidence from Non-linear Autoregressive Distributed Lag Model
}

\author{
Osaretin Kayode Omoregie ${ }^{1}$ \\ Sodik Adejonwo Olofin ${ }^{2}$ \\ ${ }^{*}$ Fredrick Ikpesu ${ }^{1}$ \\ 'Pinl-Atlintic Iniversitt, Lagos, ligeria \\ 20balemii Lwolowo Iniversity, Ile-Ife, ligeriia

\begin{abstract}
The purpose of this study was to investigate and analyze the relationship between foreign exchange and capital market dynamics in Nigeria from January 1999 to February 2018. The study deployed the Non-Linear-ARDL model to study the dynamics of exchange rate and the capital market in Nigeria. The research outcome revealed that a rise (fall) in all-share-index is related to real exchange rate depreciation (appreciation), while real exchange rate depreciation (appreciation) is associated with an increase (decrease) in all-share-index. Besides, the research outcome also showed that there is a presence of timespecific long-run, bi-directional, and unidirectional causality with stronger interrelation after the Global Financial Crisis. The study recommends that to properly hedge and diversify portfolio against potential risk in these two markets, market players need to understand the dynamics between them.

Keywords: Real exchange rate, capital market, stock-index, NARDL, causality

JEL: C1, C5, G1, G15
\end{abstract}

Following the 2008 global financial crisis, the increased integration of economies has led to increased volatility and interdependence between the capital market and the exchange rate. Particularly, the free fall of oil price in the second half of 2014 spelt severe pressure and fluctuations on Nigeria's economic indicators with an attendant exchange rate crisis. In response, the all-share-index of the Nigerian Stock Exchange crashed by over 30 percent from 42,482.48 index points in June 2014 to 29,597.79 index points in the same period of 2016. Exchange rate is quite influential to the global business cycle and its movement reflects the competitiveness of a country in the international trade market (Ajayi and Mougoue, 1996; Alley, 2018; Dornbusch and Fischer, 1980). Not less can be said about the stock market for the speculative activities happening within it, which leads to uncertainty for market operators (Maku and Atanda, 2010; Tule, Dogo and Uzonwanne, 2018). Given the critical implications of fluctuations in these variables on each other and the economy, stability in both markets has become a great concern for academics and market players. Their continuous variation is generating unending discussion in the literature (Agrawal, Srivastav and Srivastava, 2010; Aydemir and Demirhan, 2009; Fowowe, 2015; Tursoy, 2017). 
Theoretical guidance from Dornbusch and Fischer (1980) emphasized exchange rate as the key driver of stock market following productivity and trade efficiency, which culminates to gains in firm value. On the contrary, Branson (1981), and Frankel (1983) opined that stock market movements drive exchange rate via capital account transactions. Thus, shocks in any of the two markets influence the other, which can equally be complementary. For instance, there can be an occasion when the current account runs in deficit, and the exchange rate appreciates rather than depreciating following a deficit in the capital account that accrues from the bullish capital market. Likewise, it is possible for severe outflows of foreign investment or ploughing back of internationally owned assets to neutralize the effect of a current account surplus, and exchange rate depreciates.

Given the contentious findings on the dynamics between exchange rate and the capital market, this paper seeks to understand the link from a Non-linear-ARDL model perspective. The model provides a robust method of modelling stochastic relationships between variables of different order of integration and an efficient short and long-run coefficient estimates (Arize, Malindretos and Igwe, 2017; Choudhry, Hassan and Papadimitriou, 2014). The volatile and oscillatory nature of changes in these variables motivate the adoption of non-linear estimation as asymmetry in this form can have directional and sensitivity effects on estimated coefficients (Bahmani-Oskooee and Saha, 2015; Choudhry et al., 2014). Literature shows the absence of studies in the light of this model. Furthermore, structural changes, as manifested by the global financial crisis (GFC) and recent commodity price slump, have a way of influencing relationships among variables, and studies at different time periods have found diverging evidence on the subject matter. The lingering question now is "what are the dynamic relationship between exchange rate and the capital market in light of this new model and over time changes?" Therefore, this study analyses the dynamics with time variation to generate timespecific findings on how the variables of interest have fared during and after significant recent economic challenges, as mentioned.

Findings from this study suggest the presence of a direct link between exchange rate and the capital market with an evident time-specific swing in the direction of causality. These findings are significant in investment and policy decision making. Given the increasing effort by the government to ensure the stability of the foreign exchange market, boost confidence in the capital market, attract foreign investment and achieve sustained growth, this study will help investors in hedging, portfolio diversification, and trend forecast decisions. Likewise, the policy institutions will be well equipped to track the movements within the two markets.

The study arranges the remaining sections as follows: Section 2 reviews the related literature, while Section 3 presents the methodology. Section 4 presents empirical results, while Section 5 discusses the findings. Sections 6,7 , and 8 present the conclusion, implications, and limitations and future 


\section{Omoregie et al.}

directions, respectively.

\section{LITERATURE REVIEW}

\section{Theoretical Underpinnings}

The theories underpinning the relationship between exchange rate and stock market are the floworiented model approach and the stock-oriented model approach. These theories assume that there is a causal link between exchange rate and stock price. The flow-oriented model, also referred to as a traditional theory, was advanced by Dornbusch and Fisher (1980). The traditional theory assumes that movement in the exchange rate has balance-sheet and income effects on a firm with resultant effects on the firm's share price. Hence, the theory affirms that movement in the exchange rate leads to changes in the stock market.

Furthermore, the theory assumes that changes in exchange rate alter a country's trade balance and the international competitiveness of the firm. This implies that exchange rate changes affect a country's output and real income. According to the theory, there is a causal relationship between exchange rate and stock price in which causality runs from exchange rate to the stock prices. This implies that changes in exchange rate affect the competitiveness of the firm. For instance, an appreciation of the exchange rate would make goods and services to be expensive in the global market, thus affecting exporters adversely. This, in turn, will bring about a decline in firm export and profit. The decline in profit will make the firm lose competitiveness in the domestic stock market, thus leading to a fall in the firm share price.

However, recent expansion in international demand for equity and associated increased money demand have given prominence to the portfolio-balance theory as postulated by Branson (1981), and Frankel (1983). The portfolio-balance theory, also known as the "Stock-Oriented" approach, proposed that movement in the stock market leads to variations in the exchange rate. This theory asserts that movement in stock prices Granger causes movement in exchange rate through capital account transaction. The main tenet of the theory is that movement in stock prices affects exchange rate. By implication, the bullish (bearish) trend in the capital market attracts (repels) foreign capital inflows, and this increases (decreases) the demand for domestic currency leading to exchange appreciation (depreciation).

\section{Empirical Review}

Foremost empirical studies on stock-index and exchange rate had been conducted in developed economies. Findings from Franck and Young (1972) indicated that there was an absence of a significant link between stock-index and exchange rate. The findings of later studies like Bodnar and 
International Journal of Management, Economics and Social Sciences

Gentry (1993), and Bartov and Bodnar (1994) were consistent with Franck and Young (1972). In contrast, Jorion (1990) reported quite a moderate link between US-dollar exchange-rate-returns and stock market returns. Solnik (1987) employed quarterly data from 1973 to 1983 and showed that the link between domestic stock-returns and the real exchange rate was negative. Likewise, Ma and Kao (1990), and Moore and Wang (2014) found a negative link between stock price and exchange rate given that the appreciation of the exchange rate would deteriorate stock price. However, evidence from Aggarwal (1981), as well as Giovannini and Jorion (1987), revealed that US stock prices and dollar exchange rate correlated positively.

Recent studies have focused on emerging economies. For instance, Zolfaghari and Sahabi (2016), adopting a Two-Regime-ARDL model, indicated that exchange rate variation has significant and varying impacts on the value-at-risk of listed oil companies in Iran Stock Exchange. Using a timevarying co-movement analytical technique, Bashir, Hussain and Zebende (2016) found the presence of positive cross-correlation between stock price and exchange rate in Latin-American countries.

While studying twelve emerging economies, Hajilee and Al-Nasser (2014) found a short-run effect on the stock exchange with varying directions of relationships. Besides, their study revealed that not all the sampled countries exhibited a long-run link among the variables. Agrawal et al. (2010) reported a unidirectional causality between the variables with causality running from Nifty returns to exchange rates. Hajilee and Al-Nasser (2014), on the contrary, concluded that exchange rate uncertainty was causative of the decision to hold foreign currency. Similar conclusions were drawn by Adjasi, Harvey and Agyapong (2008), Beer and Hebein (2011), Ebrahim (2000), and Kang and Yoon (2013).

Aydemir and Demirhan (2009) found a bi-directional causal link between the stock market index and exchange rate in Turkey. Likewise, Jebran and labal (2016), using the E-GARCH model, revealed for Pakistan, China, Hong Kong, and Sri Lanka that there exists a bi-directional asymmetric volatility spillover between the foreign exchange market and the stock market. This equally coincides with findings of Andreou, Matsi and Savvides (2013), Aydemir and Demirhan (2009), Bahmani-Oskooee and Sohrabian (1992), Chkili (2012), Choi, Fang and Fu (2010), Granger, Haung and Yang (2000), Khan and Ali (2015), Xiong and Han (2015), Yang (2017), and Zhao (2010) who found mixed evidence for the set of countries considered.

Studies on Nigeria have equally reported mixed result. Maku and Atanda (2010), Osamwonyi and Evbayiro-Osagie (2012), and Nkoro and Uko (2016) provided evidence on the responsiveness of the stock market to the exchange rate movements. Fowowe (2015), Okpara and Odionye (2012), and Olugbenga (2012) empirically found unidirectional transmission of shocks from the exchange rate to the equity market in Nigeria. Tule et al. (2018) reported a bi-directional spillover between the two markets using the VARMA-AGARCH model. In the same vein, Salisu and Oloko (2015) reported some 


\section{Omoregie et al.}

reverse spillovers between the variables using a similar method. Likewise, Aliyu (2009) found strong evidence of a long-run bi-directional relationship between stock prices and exchange rate. Meanwhile, Zubair (2013) reported an absence of direct linkage between ALSI and the exchange rate.

Given supportive empirical evidence for both the flow-oriented and the stock-oriented approaches alongside the volatile and oscillatory nature of the exchange rate and all-share-index, BahmaniOskooee and Saha (2015) called for the adoption of non-linear estimation of the relationships. Empirically, Ebrahim (2000), Jebran and labal (2016), Lo and Morley (2015), Salisu and Oloko (2015), and Tule et al. (2018) had provided evidence that suggests the existence of a non-linear relationship between the variables of interest. Present study intends to contribute to the literature and practice by providing new time-specific evidence on the dynamics of exchange rate and stock-index in Nigeria by employing the NARDL model.

\section{METHODOLOGY}

\section{-Data}

This study used monthly data of exchange rate and stock market index sourced from the Nigerian Stock Exchange (NSE), and Central Bank of Nigeria (CBN) between the periods January 1999 to February 2018. This study divided the data set into four phases. The first phase covers the full length of the data set while the second phase covers the period before the global financial crisis (GFC) of 2008 (January 1999 - December 2007). The third phase covers the period of the global financial

crisis and after (January 2008 - February 2018). The last phase covers the period of the recent slip in the oil price (January 2014 - February 2018).

Figure 1 (see Appendix-I) depicts the trend of exchange rate and all-share-index overtime with blue and red lines, respectively. Significant changes in both markets were associated with the global financial crisis of 2008; the aftermath of which saw the exchange rate depreciated considerably, and the ASI fell from 65,652.38 index points in February 2008 to $23,377.00$ index points in the same month of the following year. Though, there is a noticeable process of recovery, but the market has not recovered to its level pre-global financial crisis. Another notable movement in these markets was tied to the free fall in the oil price of 2014. This put severe pressure on exchange rate as well as the stock index. Equally, periods of stable exchange rate are associated with improvements in the stock-index. Following these notable changes, both markets adjust almost at the same time to economic situations. In addition, they moved in the opposite direction; it is thus vital to understand how they influence each other.

Table 1 presents the descriptive statistics for real exchange rate and all-share-index. Both variables have their mean increasing over time with all-share-index having the most deviation before the global 
financial crisis and real exchange rate after. This implies that all-share-index was more volatile before the global financial crisis while the real exchange rate was more volatile after the crisis.

\begin{tabular}{lcccccccc}
\hline & & Mean & Std. Dev. & Skewness & Kurtosis & Jarque-Bera & $p$-value & Observations \\
\hline $1999 / 01-2018 / 02$ & $R E R$ & 4.9845 & 0.2885 & 1.1883 & 4.2872 & 70.011 & 0.0001 & 230 \\
& $A S I$ & 9.9953 & 0.6118 & -0.8492 & 3.1022 & 27.743 & 0.0001 & 230 \\
$1999 / 01-2007 / 12$ & $R E R$ & 4.7830 & 0.1156 & -0.9294 & 2.6537 & 16.088 & 0.0003 & 108 \\
& $A S I$ & 9.6408 & 0.6897 & 0.0075 & 2.0180 & 4.3406 & 0.1141 & 108 \\
$2008 / 01-2018 / 02$ & $R E R$ & 5.1630 & 0.2782 & 1.0487 & 3.0913 & 22.404 & 0.0001 & 122 \\
& $A S I$ & 10.309 & 0.2761 & 0.7068 & 2.9829 & 10.158 & 0.0062 & 122 \\
$2014 / 01-2018 / 02$ & $R E R$ & 5.4060 & 0.2747 & 0.0961 & 1.3547 & 5.7169 & 0.0573 & 50 \\
& $A S I$ & 10.379 & 0.1805 & 0.0828 & 1.6762 & 3.7083 & 0.1566 & 50 \\
\hline Source & & & & & & & & \\
\hline
\end{tabular}

Source: Authors' Computation

Table 1. Descriptive Statistics of Log of Exchange Rate and All Share Index

\section{-Theoretical Model}

Exchange rate measures the rate at which foreign currency (particularly the US-dollar) change for domestic currency. Invariably, it is the value of one country currency relative to another (Hajilee and Al-Nasser, 2014; Tursoy, 2017). Conventional calculation of real exchange rate is as follows:

$$
r_{N}=E_{N}\left(\frac{P^{*}}{P_{N}}\right)
$$

where $r_{N}, E_{N}, P_{N}$ and $P^{*}$ are real exchange rate, nominal naira exchange rate, price level captured by the Consumer Price Index (CPI) in Nigeria and price level in the foreign country (US-CPI), respectively.

Following the proposition of traditional and portfolio-balance theories, this study models the link between the real exchange rate and the capital market variable as:

$$
\begin{aligned}
& R E R_{t}=\phi_{1}+\pi_{1} A S I_{t}+\mu_{1 t} \\
& A S I_{t}=\phi_{2}+\pi_{2} R E R_{t}+\mu_{2 t}
\end{aligned}
$$

where RER and ASI are real exchange rate and All Share Index (movement of share price of all listed firms) in their log form. Here, omitted variable will not be a concern as the properties of the empirical 


\section{Omoregie et al.}

model adopted include lagged variables of positive and negative changes in the variables of interest.

\section{-Empirical Model}

\section{Non-Linear Autoregressive Distributed Lag (NARDL) Model}

In light of the NARDL model advanced by Shin, Yu and Greenwood-Nimmo (2014), this paper explored the dynamic link between exchange rate and the capital market. NARDL is very useful given the way it models the stochastic relationship between variables of different order of integration. It also provides better efficient short-run and long-run coefficient estimates (Arize et al., 2017; Choudhry et al., 2014). Based on the linear-ARDL model proposed by Pesaran and Shin (1999), the NARDL models the dependent variable as a function of its lagged variables and lagged variables of independent variables. The linear-ARDL model is expressed compactly as:

$$
\begin{gathered}
\Phi(L) y_{t}=\alpha_{0}+\alpha_{1} w_{1}+\beta^{\prime}(L) x_{i t}+\varepsilon_{t} \\
\text { where } \Phi(L)=1=\sum_{i=1}^{\infty} \Phi_{i} L^{i} \text { and } \beta^{\prime}(L)=\sum_{j=1}^{\infty} \beta_{j} L^{j} \text { as } L, y_{t}, x_{i t}, w_{1} \text { and } \varepsilon_{t} \text { represent lag operator of dependent }
\end{gathered}
$$
variable, vector of independent variables, vector of deterministic variables with fixed lags and the error term respectively. As a caveat, ARDL approach is suitable for variable of different orders but limited to $I(0)$ and $I(1)$; the estimates might be biased by $I(2)$ variables (Arize, 2017; Hung-Pin, 2014; Shahbaz, Ahmed and Ali, 2008).

Based on the oscillatory nature of exchange rate and stock market index, this study modelled both markets using the NARDL version as expressed below. Also, following Shin et al. (2014) who adopted a partial sum decomposition of variables to the ARDL model, the long-run association between the hypothetical variables $x$ and $y$ are expressed as:

$$
y_{t}=\beta^{+} x_{t}^{+}+\beta^{-} x_{t}^{-}+u_{t}, \quad x_{t}=x_{0}+x_{t}^{+}+x_{t}^{-}
$$

where $\beta^{+}$and $\beta^{-}$are long-run parameters, ${ }^{x_{t}}$ is a vector of decomposed partial sums processes of positive and negative changes which are expressed as:

$$
x_{t}^{+}=\sum_{j=1}^{t} \Delta x_{j}^{+}=\sum_{j=1}^{t} \max \left(\Delta x_{j}, \bar{x}\right), \quad x_{t}^{-}=\sum_{j=1}^{t} \Delta x_{j}^{-}=\sum_{j=1}^{t} \min \left(\Delta x_{j}, \bar{x}\right)
$$

This splits the changes in the independent variables into positive and negative changes by setting the threshold equal to their respective mean (Choudhry et al., 2014; Shin et al., 2014). By combining Equations 4 and 5 , the typical NARDL model is expressed as: 


$$
\Delta y_{t}=\rho y_{t-1}+\theta^{+} x_{t-1}^{+}+\theta^{-} x_{t-1}^{-}+\sum_{j=1}^{\rho-1} \varphi_{j} \Delta y_{t-j}+\sum_{j=0}^{q}\left(\eta_{j}^{+} \Delta x_{t-j}^{+}+\eta_{j}^{-} \Delta x_{t-j}^{-}\right)+\varepsilon_{t} \quad j=1,2, \ldots, q
$$

With respect to the objective of this study, the following equation models exchange rate and allshare-index in their natural log form represented as RER and ASI respectively for better distributional properties.

$$
\begin{aligned}
& R E R_{t}=f\left(A S I_{t}^{+}, A S I_{t}^{-}\right) \\
& A S I_{t}=f\left(R E R_{t}^{+}, R E R_{t}^{-}\right)
\end{aligned}
$$

In stochastic terms, the relationship is modelled as:

$$
\begin{aligned}
& \Delta R E R_{t}=\alpha_{1}+\rho_{1} R E R_{t-1}+\theta_{1}^{+} A S I_{t-1}^{+}+\theta_{1}^{-} A S I_{t-1}^{-}+\sum_{j=1}^{\rho-1} \varphi_{1 j} \Delta R E R_{t-j}+\sum_{j=0}^{q}\left(\eta_{1 j}^{+} \Delta A S I_{t-j}^{+}+\eta_{1 j}^{-} \Delta A S I_{t-j}^{-}\right)+\varepsilon_{1 t} \\
& \Delta A S I_{t}=\alpha_{2}+\rho_{2} A S I_{t-1}+\theta_{2}^{+} R E R_{t-1}^{+}+\theta_{2}^{-} R E R_{t-1}^{-}+\sum_{j=1}^{\rho-1} \varphi_{2 j} \Delta A S I_{t-j}+\sum_{j=0}^{q}\left(\eta_{2 j}^{+} \Delta R E R_{t-j}^{+}+\eta_{2 j}^{-} \Delta R E R_{t-j}^{-}\right)+\varepsilon_{2 t}
\end{aligned}
$$

where $R E R_{t-i}^{+}, R E R_{t-i}^{-}, A S I_{t-i}^{+}$, and $A S I_{t-i}^{-}$represent the decomposed partial sums of exchange rate and allshare-index. $\sum_{j=0}^{q}\left(\eta_{j}^{+} \Delta R E R_{t-j}^{+}+\eta_{j}^{-} \Delta R E R_{t-j}^{-}\right)$and $\sum_{j=0}^{q}\left(\eta_{j}^{+} \Delta A S I_{t-j}^{+}+\eta_{j}^{-} \Delta A S I_{t-j}^{-}\right)$represent the sums of the short-run positive and negative partial sum processes of exchange rate and all-share-index with short-run parameters of $\eta_{j}^{+}$and $\eta_{j}^{+}$as $\theta_{j}^{+}$and $\theta_{j}^{+}$represent the long-run parameters.

Implementation of the NARDL model follows from conducting the bound co-integration test, estimation of long-run and short-run relationship and the establish causal link. Short- and long-run relationship are established by the significance $\left(\eta_{j}^{+}\right.$and $\left.\eta_{j}^{+}\right)$and $\left(\theta_{j}^{+}\right.$and $\left.\theta_{j}^{+}\right)$respectively using the normal t-test. Employing the Bound-test as proposed by Pesaran, Shin and Smith (2001), this study adopted the restricted version of NARDL in the form of conditional Error Correction Model (ECM) to establish the co-integration expressed in Equation 9 (Choudhry et al., 2014; Morley, 2006; Shahbaz et al., 2008).

$$
\begin{aligned}
& \Delta R E R_{t}=\alpha_{1}+\sum_{j=1}^{\rho-1} \varphi_{1 j} \Delta R E R_{t-j}+\sum_{j=0}^{q}\left(\eta_{1 j}^{+} \Delta A S I_{t-j}^{+}+\eta_{1 j}^{-} \Delta A S I_{t-j}^{-}\right)+\lambda_{1} E C M_{1 t-1}+\varepsilon_{1 t} \\
& \Delta A S I_{t}=\alpha_{2}+\sum_{j=1}^{\rho-1} \varphi_{2 j} \Delta A S I_{t-j}+\sum_{j=0}^{q}\left(\eta_{2 j}^{+} \Delta R E R_{t-j}^{+}+\eta_{2 j}^{-} \Delta R E R_{t-j}^{-}\right)+\lambda_{2} E C M_{2 t-1}+\varepsilon_{2 t}
\end{aligned}
$$

The ECM term represents the adjustment parameter. Following Pesaran et al. (2001), this study 


\section{Omoregie et al.}

tests the null of no co-integration by comparing the $f$-statistic from the components of the ECM term with the critical values of the two generated bounds of $I(0)$ and $I$ (1). An $f$-statistic above the $I(1)$ bound, irrespective of the order of integration of the variables $(I(0)$ or $I(1))$, leads to rejection of the null hypothesis and acceptance of the presence of co-integration. Otherwise, if the $f$-statistic falls below the $I(0)$ bound, the null hypothesis is not rejected. However, it becomes inconclusive if the $f$ statistic fall in between $I(0)$ and $I(1)$ bounds. It then becomes essential to have tested for unit-root before implementing this method (Arize, 2017; Shahbaz et al., 2008; Van-Hoang, Lahiani and Heller, 2016). If the set of variables are known to be $I(1)$ all through, then the decision is based on the $I(1)$ bound. If the variables are all $I(0)$, the $I(0)$ bound is used for the decision.

The study also employed the NARDL causality using the Wald test. The ECM version from the restricted NARDL model of Equation 9 can be used to conduct the conventional short-run bi-variate Granger causality (Granger et al., 2000; Morley, 2006). As noted by Engle and Granger (1987), if there is co-integration among two variables, there is a possibility of at least one direction of causality which requires that the variables are integrated of order one. Provided the orders of integration are between $I$ (0) and $I(1)$, the test is still valid for an ARDL model (Tursoy, 2017). The short-run causality test is represented as $H_{0}: \eta_{1}^{+}=\eta_{2}^{+}=\ldots \eta_{q}^{+}=0$ and $H_{0}: \eta_{1}^{-}=\eta_{2}^{-}=\ldots \eta_{q}^{-}=0$. Furthermore, the significance of the lagged components of the ECMs is used to establish the long-run causality with ${ }^{H_{0}}: \lambda_{i}$ using $t$-test (Shahbaz et al., 2008). The strong causality is a hybrid of both short-run and long-run causality with $H_{0}: \eta_{1}^{+}=\eta_{2}^{+}=\ldots \eta_{q}^{+}=\lambda_{i}^{+}=0$ and $H_{0}: \eta_{1}^{-}=\eta_{2}^{-}=\ldots \eta_{q}^{-}=\lambda_{i}^{-}=0$ with associated positive or negative component of the ECM (see Hung-Pin, 2014).

\section{Non-linear Unit Root Tests}

The unit-root test was used to establish the stability of the stochastic process and identify the order of integration. It is crucial because an inappropriate combination of variables with different integration can lead to a spurious regression and conclusion made from such will be misleading (Cuestas and Regis, 2008; Habimana, Mansson and Sjolander, 2018). This study applied the non-linear unit-root tests developed by Kapetanios, Shin and Snell (2003) (KPSS), and Sollis (2004). This is based on the recommendation of Emirmahmutoglu and Omay (2014), and Bahmani-Oskooee and Saha (2015), and the findings from Salisu and Oloko (2015), and Tule et al. (2018) which emphasized that the variables of interest exhibit non-linear tendency. Extant literature has also shown that the standard linear methods of testing unit-root are deficient against non-linear processes. Besides, an incorrect unit-root specification may bias the result of the test (Cuestas and Regis, 2008; Guris, 2017; Zhang, 2015) 
Kapetanios et al. (2003) demonstrated that the ADF of Dickey and Fuller (1981) is weak when the stochastic process is stationary but non-linear. The testing procedure of the KPSS test accounts for non-linearity in the stochastic process of time-series by estimating an Exponential Smooth Transition Autoregressive (ESTAR) model expressed as:

$$
\Delta y_{t}=\phi y_{t-1}+\theta y_{t-1}\left[1-e^{\left(-\gamma y_{t-d}^{2}\right)}\right]+\varepsilon_{t}
$$

Kapetanios et al. (2003), therefore, subject Equation 10 to a first-order Taylor Series expansion to derive an auxiliary unit-root expression as in Equation 11, which is equally augmented as in the ADF:

$$
\Delta y_{t}=\eta+\delta y_{t-d}^{3}+\sum_{t=1}^{p} \beta_{i} \Delta y_{t-i}+v_{t}
$$

The KPSS tests $H_{0}: \delta=0$ against $H_{0}: \delta<0$. That is, a null of unit-root against the alternative of nonlinear ESTAR stationary process. The KPSS test is based on a non-standardized $t$-distribution due to the infinite variance of the series under the null hypothesis. It can then be conducted using $t$-test defined as $t=\hat{\delta} / \operatorname{se}(\hat{\delta})$ where $\delta$ is an OLS estimate of $\delta$ and $\operatorname{se}(\hat{\delta})$ represents an estimated standard error of $\delta$. Also, Kapetanios et al. (2003) provided the tabulated critical values for 1 percent, 5 percent, and 10 percent.

As robust as KPSS is, it, however, does not account for the possibility of structural breaks and asymmetry (Emirmahmutoglu and Omay, 2014). Zivot and Andrews (1992) among others, proposed a procedure that accounts for a one-point break with an endogenously selected date. Leybourne, Newbold and Vougas (1998), however, argued that identification of an instantaneous breakpoint for macroeconomic data might be misleading. Thus, they suggested a model that captures gradual structural changes.

This study adopted the Sillos (2004) procedure that captures the gradual and asymmetric changes of time series by inducing asymmetry in the non-linear ESTAR unit-root testing of KPSS. This is done by invoking a Smooth Transition Threshold Autoregressive (ST-TAR) unit-root approach by modelling the structural changes in the series as:

$$
y_{t}=\alpha_{1}+\beta_{1} t+\alpha_{2} S_{t}(\gamma, \tau)+\beta_{2} t S_{t}(\gamma, \tau)+v_{t}
$$

where $v_{t}$ is a zero-mean I(0) process. $S_{t}(\gamma, \tau)$ is a logistic smooth transition function based on sample 


\section{Omoregie et al.}

size $T$ as $S_{t}(\gamma, \tau)=\left(1+e^{(-\gamma[t-\tau T]}\right)^{-1} . S_{t}(\gamma, \tau)$ is a continuous function ranging from zero to one while $t$ represents the transition mid-point. The parameter $t$ determines the timing of the transition mid-point and ${ }^{\tau}$ represents the speed of transition between regimes. Estimation of this model follows the nonlinear least squares method and then subjecting the residual ${ }^{v_{t}}$ to an asymmetric-ADF regression model as in Equation 13.

$$
v_{t}=I_{t} \rho_{1} v_{t-1}+\left(1-I_{t}\right) \rho_{2} v_{t-1}+\sum_{i=1}^{k} \phi_{i} \Delta v_{t-i}+\zeta
$$

where $I_{t}=1$ when $v_{t-1} \geq 0, I_{t}=0$ when $v_{t-1}^{<0}$ and $\zeta$ is equally a zero-mean stationary process. Then we test $H_{0}: \rho_{1}=\rho_{2}=0$ that suggests $v_{t}$ and then $y_{t}$ contains unit-root against $H_{0}: \rho_{1}=\rho_{2}<0$ that suggests ST-TAR stationary in $y_{t}$ with symmetric adjustment. Meanwhile, if $H_{0}: \rho_{1}<0, \rho_{2}<0$ and $\rho_{1} \neq \rho_{2}$, it suggests $y_{t}$ is ST-TAR stationary with asymmetric adjustment. Sollis (2004), suggested that the test can be conducted using the most significant of the $t$-statistics from those testing $\rho_{1}=0$ and $\rho_{2}=0$ or the $f$-statistics for testing $\rho_{1}=\rho_{2}=0$ as expressed in Equation 6 .

\section{RESULTS}

\section{-Unit Root Test}

Results of the non-linear unit-root tests as shown in Table 2 reflect the presence of unit root at level for RER. However, at first difference, RER became stationary $I(1)$. The unit-root tests further revealed that ASI is stationary at level 1(0) as their $p$-values are less than 0.05 .

\begin{tabular}{|c|c|c|c|c|c|c|c|c|c|}
\hline \multicolumn{5}{|c|}{ Levels } & \multicolumn{4}{|c|}{ 1st Difference } & \multirow[b]{2}{*}{ Decision } \\
\hline & KPSS & & Sollis & & KPSS & & Sollis & & \\
\hline$R E R$ & 0.3120 & $(0.7554)$ & 0.2242 & $(0.7993)$ & $-6.4861^{* * *}$ & $(0.0001)$ & $32.826^{* * *}$ & $(0.0001)$ & $I(1)$ \\
\hline$A S I$ & $-2.1669^{*}$ & $(0.0313)$ & $3.4053^{*}$ & $(0.0350)$ & $-5.6489^{* * *}$ & $(0.0001)$ & $16.397^{* * *}$ & $(0.0001)$ & $I(0)$ \\
\hline
\end{tabular}

Source: Authors' Computation

Note: Values in parentheses represent $p$-values

Table 2. Unit Root Test

\section{-Co-integration Test Results}

Table 3 presents the outcome of the NARDL bound-test. For the model $R E R=f\left(A S I^{+}, A S I^{-}\right)$, there is 
absence of co-integration between the variables for the different time variation. For the model $A S I=f\left(R E R^{+}, R E R^{-}\right)$, co-integration is established for the period after the GFC (2008/01-2018/02) . This suggests that movements in ASI do not have long-run effect on exchange rate movement.

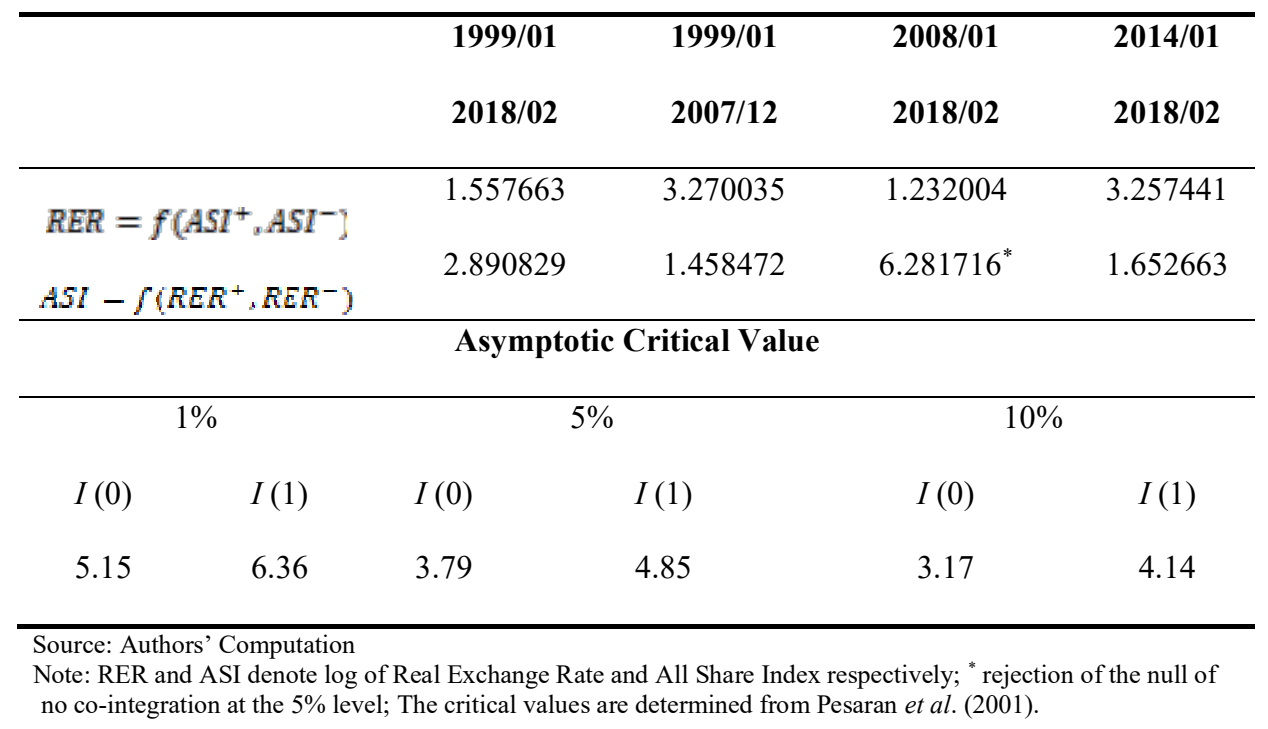

Table 3. Bound Co-integration Test

-Non-linear Autoregressive Distributed Lag Model Estimation Results

The outcome of the co-integration test from the Bound-test and the significance of the ECM terms are quite conflicting: some are consistent while others are not. In such a scenario, Arize (2017) alongside Arize et al. (2017) noted that the $t$-ratio of the ECM-term holds superior ground given the shortcomings of the Pesaran et al. (2001) critical values. Therefore, the result of the short-run relationship, long-run adjustment (ECM) parameter and long-run relationship are presented in that order for $R E R=f\left(A S I^{+}, A S I^{-}\right)$and $A S I=f\left(R E R^{+}, R E R^{-}\right)$models. Tables $4 \mathrm{a}$ and $4 \mathrm{~b}$ (see Appendix-II) presents the NARDL estimates for the different time variation. For model $R E R=f\left(A S I^{+}, A S I^{-}\right)$, the estimates for the first phase which covers the full length of the data set showed that in the short-run, positive changes in ASI have positive effect on RER and negative changes in ASI have negative effect on RER with no significant long-run.

In the period before the GFC, movement in ASI was insignificant to RER both in the short- and long-run. In the period after the GFC, the ASI became significant and held similar outcomes as the full data. However, in recent time, after the 2014 oil price slip, the adjustment parameter of the ECM is quite significant and negative. This implies that long-run can exist and ASI converges to long-run 


\section{Omoregie et al.}

equilibrium by 17.9 percent each month. It is further shown that only negative changes in ASI are significant to RER and have negative and instantaneous effects in both short- and long-run.

Conversely, the result for $A S I=f\left(R E R^{+}, R E R^{-}\right)$shows presence of long-run adjustment for the full sample period with 51.7 percent convergence each month. The result reveals that only positive changes in RER are significant to ASI with a negative effect in both short- and long-run. In the period before the GFC, only negative changes in RER influence ASI negatively in the short-run. In the longrun with 8.47 percent adjustment monthly rate, positive changes in RER have a positive impact on ASI, and negative changes in RER has a negative effect on the ASI. After the GFC, though there is long-run adjustment of 7.30 percent monthly, negative changes in RER have a negative impact on ASI with no significant long-run. However, RER appears insignificant to ASI in the period following the oil price fall of 2014 both in the short- and long-run.

Furthermore, the diagnostic tests carried out, as shown in Table 5 (see Appendix-III) suggest that the estimations are reasonably fit to explain the dynamics between real exchange rate and the capital market.

\section{- Non-linear Autoregressive Distributed Lag Causality Tests Results}

Findings from the causality tests as presented in Table 6 (see Appendix-IV) suggest that in the full sample period, a positive and negative change in ASI cause RER in the short-run but not in the longrun. Whereas, an adverse change in ASI actively causes RER. Conversely, positive changes from RER is revealed to cause ASI in the short- and long-run, while negative changes in RER cause ASI in the long-run. Only positive changes in RER have strong causality on ASI.

In the period before the GFC, ASI did not cause RER in the short- and long-run. Meanwhile, positive and negative changes in RER caused ASI both in the short- and long-run. After the crisis, only negative changes in the ASI cause RER in the short-run but not long-run and this have a strong causal effect. Equally, both directions of change in RER cause ASI in the short- and long-run with only positive changes in RER having strong causality on ASI. This implies that both positive and negative changes in RER lead to ASI.

Following the 2014 oil price fall, only negative changes in ASI cause RER in the short-run whereas, both positive and negative changes in ASI cause RER in the long-run and both have strong causality. Also, positive and negative change in RER does not cause ASI in both the short- and long-run.

\section{DISCUSSION}

Findings of this study are quite insightful as the ideas of both traditional and portfolio-balance theories 
International Journal of Management, Economics and Social Sciences

are materialized in the Nigerian space. Empirical evidence from the study indicates that increasing stock-index is associated with real exchange rate depreciation. Whereas, a falling stock-index is related to real exchange rate appreciation in the short and long-run. However, the long-run relationship became evident only after the 2014 oil price slump, which implies that before 2014, the effect of the stock market on the exchange rate was transient. This in in accord with the portfolio balance theory and research findings of Aggarwal (1981), and Bashir et al. (2016) but quite contrary to Aydemir and Demirhan (2009), Agrawal et al. (2010), and Zubair (2013). This is evident in foreign investors' appetite for portfolio investment in Nigeria against foreign direct investment. It further shows that the capital market is still imperfect and requires policy attention to set things straight.

Besides, real exchange rate depreciation is associated with improved stock-index. Besides, shortand long-run real exchange rate appreciation negatively influence the capital market. However, the long-run effect was only evident before the GFC and became transitory after the GFC. This finding emphasized the traditional theory before the GFC and are similar to the conclusions of Hajilee and AlNasser (2014), Kennedy and Nourizad (2016), and Lawal, Somoye and Babajide (2016) but contrary to the research findings of Ajayi and Mougoue (1996), Tsai (2012), Zubair (2013), Moore and Wang (2014), and Salisu and Oloko (2015). Against popular notion, this implies that exchange rate depreciation (appreciation) increases (decreases) the amount of naira denominated investment that can be purchased by foreign investors as such, when the capital market becomes bullish (bearish).

Further evidence revealed that the causality between real exchange rate and stock-index is bidirectional, quite similar to findings from Aliyu (2009), Bahmani-Oskooee and Sohrabian (1992), Granger et al. (2000), Jebran and Iqbal (2016), Khan and Ali (2015), and Tursoy (2017). Before the GFC, the link confirms the traditional theory with unidirectional causality running from real exchange rate to stock-index. These findings are similar to Agrawal et al. (2010), Okpara and Odionye (2012), Olugbenga (2012), Fowowe (2015), and Najaf and Najaf (2016). After the GFC, the variables exhibit bi-directional causality similar to the findings of Aliyu (2009), Bahmani-Oskooee and Sohrabian (1992), Jebran and labal (2016), Khan, and Ali (2015), and Tursoy (2017). After 2014, the link confirms the portfolio-balance theory with a unidirectional causality running from the stock-index to the exchange rate. Agrawal et al. (2010), Najaf and Najaf (2016), and Tule et al. (2018) also reported similar findings.

\section{CONCLUSION}

This study explores the dynamic link between real exchange rate and capital market in Nigeria, employing a NARDL model based on some time variation. The study adopted data based on monthly 


\section{Omoregie et al.}

frequency from 1999 to 2018. The data set was broken into four phases: the period before the GFC, the period after the GFC, the period after the 2014 oil market slump, and the full length of the data. Findings from this study show no long-run link between all-share-index and exchange rate except after 2014. Meanwhile, relating exchange rate to all-share-index shows long-run relationship before the GFC and transitory effect afterward. We found that increasing (declining) all-share-index is positively (negatively) associated with exchange rate, and appreciating (depreciating) is associated with declining (increasing) all-share-index.

Further evidence on causality suggests bi-directional causality, but in recent times, there is a unidirectional causality leading from the stock market to exchange rate. By implication, exchange rate dictated the pace of the relationship before the GFC while all-share-index does afterward. There is equally evidence of a time-specific effect on the relationship between the variables. Findings from this study thus have implications for both policy decisions, private investors, portfolio managers, and finance officers. Therefore, it is paramount for market players to understand the dynamics between these variables in order to properly hedge and diversify their portfolio against potential risk in the two markets.

\section{IMPLICATIONS}

The findings of this study suggest that there is a time-specific relationship between the exchange rate and capital markets since both cause each other. However, the stock market appears dominant in causing the exchange rate in recent times. This emphasizes how much the country's economy, particularly the capital market, integrated into the global market. The study hence, recommends that Finance Ministry, Central Bank, and the Security and Exchange Commission should keep track of both variables to articulate appropriate policies needed to drive the nation's growth.

Furthermore, although exchange rate has a link with the stock market, findings from our study showed that it does not have a causal effect in recent times. Hence, the government needs to focus on internal factors that will drive aggregate output and firm value. Since policy designs to attract investment into the financial system based on exchange rate might not be productive.

The findings further suggest that improved stock market is associated with depreciation. This could be as a result of the speculative and imperfect nature of the Nigerian capital market. Hence, the government needs to continuously improve its capital market policies so that it serves as an avenue for capital raising against mere speculative activities.

Lastly, for investors, portfolio managers, and chief executives of firms to reduce/eliminate risk in their portfolio, understanding the dynamics of exchange rate and capital market is paramount. This is 
necessary for proper diversifying and hedging of their portfolio against the potential risk that might cause value-loss.

\section{LIMITATIONS AND FUTURE DIRECTIONS}

Findings from this study provide insightful evidence on the link between the exchange rate and the capital market. The study provides some support for the flow and stock orientations but with a timespecific relationship. The dynamics between the variables have changed significantly, especially after the global financial crisis. This link became stronger after the 2014 oil price slump, but the ASI dictates the relationship. Recent realities have seen benchmark rates adjusted to drive stability in exchange rate. This has significant implications for the capital market, especially as the Central Bank of Nigeria has chosen a multiple exchange rate and interest rate environment.

This study is limited in scope; it does not consider the multiplicity of the exchange rate and interest rate. It would be necessary for future studies to provide evidence on the potential effect of the misalignments created by the multiple windows in exchange rate and interest rate in the dynamics of these variables.

\section{REFERENCES}

Adjasi, C., Harvey, S. \& Agyapong, D. (2008). Effect of exchange rate volatility on the Ghana Stock Exchange. African Journal of Accounting, Economics, Finance and Banking Research, 3(3): 28-47.

Aggarwal, R. (1981). Exchange rates and stock prices: A study of the US capital markets under floating exchange rates. Akron Business and Economic Review, 12(1): 7-12.

Agrawal, G., Srivastav, A. \& Srivastava, A. (2010). A study of exchange rates movement and stock market volatility. International Journal of Business and Management, 5(12): 62-73.

Ajayi, R. \& Mougoue, M. (1996). On the dynamic relation between stock prices and exchange rates. Journal of Financial Research, 19(2): 193-207.

Aliyu, S. (2009). Stock prices and exchange rate interactions in Nigeria: A maiden intra-global financial crisis investigation. IUP Journal of Financial Economics, 7(3): 8-23.

Alley, I. (2018). Oil price and USD-Naira exchange rate crash: Can economic diversification save the Naira? Energy Policy, 118, 245-256.

Andreou, E., Matsi, M. \& Savvides, A. (2013). Stock and foreign exchange market linkages in emerging economies. Journal of International Financial Markets, Institutions and Money, 27, 248-268.

Arize, A. (2017). A convenient method for the estimation of ARDL parameters and test statistics: USA trade balance and real effective exchange rate relation. International Review of Economics and Finance, 50, 75-84.

Arize, A., Malindretos, J. \& Igwe, E. U. (2017). Do exchange rate changes improve the trade balance: An asymmetric nonlinear cointegration approach. International Review of Economics and Finance, 49, 313-326.

Aydemir, O. \& Demirhan, E. (2009). The relationship between stock prices and exchange rates: Evidence from Turkey. International Research Journal of Finance and Economics, 23(2): 207-215.

Bahmani-Oskooee, M. \& Saha, S. (2015). On the relation between stock prices and exchange rates: a review article. Journal of Economic Studies, 42(4): 707-732.

Bahmani-Oskooee, M. \& Sohrabian, A. (1992). Stock prices and the effective exchange rate of the dollar. Applied economics, 24(4): 459-464.

Bartov, E. \& Bodnar, G. (1994). Firm valuation, earnings expectations, and the exchange-rate exposure effect. The Journal of Finance, 49(5): 1755-1785.

Bashir, U., Yu, Y., Hussain, M. \& Zebende, G. (2016). Do foreign exchange and equity markets co-move in Latin American region? De-trended cross-correlation approach. Physica A: Statistical Mechanics and its Applications, 462, 889-897.

Beer, F. \& Hebein, F. (2011). An Assessment of the stock market and exchange rate dynamics in industrialized and emerging markets. International Business Economic Research Journal, 7(8): 59-70.

Bodnar, G. \& Gentry, W. (1993). Exchange rate exposure and industry characteristics: evidence from Canada, Japan, and the 


\section{Omoregie et al.}

USA. Journal of international Money and Finance, 12(1): 29-45.

Branson, W. (1981). Macroeconomic determinants of real exchange rates. The National Bureau of Economic Research.

Chkili, W. (2012). The dynamic relationship between exchange rates and stock returns in emerging countries: volatility spill-over and portfolio management. International Journal of Management Science and Engineering Management, 7(4): $253-262$.

Choi, D., Fang, V. \& Fu, T. (2010). Volatility spill-overs between New Zealand stock market returns and exchange rate changes before and after the 1997 Asian financial crisis. Asian Journal of Finance and Accounting, 1(2): 106-117.

Choudhry, T., Hassan, S. \& Papadimitriou, F. (2014). UK imports, third country effect and the global financial crisis: Evidence from the asymmetric ARDL method. International Review of Financial Analysis, 32, 199-208. https://doi.org/10.1016/j.irfa.2013.11.003

Cuestas, J. \& Regis, P. (2008). Testing for PPP in Australia: evidence from unit root tests against nonlinear trend stationarity alternatives. Economics Bulletin, 3(27): 1-9.

Cushman, D. (2007). A portfolio balance approach to the Canadian- US exchange rate. Review of Financial Economics, 16(3): 305-320.

Dickey, D. \& Fuller, W. (1981). Likelihood ratio statistics for autoregressive time series with a unit root. Econometrica, 49(4): 1057-1072.

Dornbusch, R. \& Fischer, S. (1980). Exchange rates and the current account. The American Economic Review, 70(5): 960971.

Ebrahim, S. K. (2000). Volatility transmission between foreign exchange and money markets. Ottawa: Bank of Canada.

Emirmahmutoglu, F. \& Omay, T. (2014). Reexamining the PPP hypothesis: A nonlinear asymmetric heterogeneous panel unit root test. Economic Modelling, 40:184-190. http://dx.doi.org/10.1016/j.econmod.2014.03.028

Engle, R. \& Granger, C. (1987). Co-integration and error-correction: Representation, estimation and testing. Econometrica, 55 , 251-276.

Fowowe, B. (2015). The relationship between stock prices and exchange rates in South Africa and Nigeria: Structural breaks analysis. International Review of Applied Economics, 29(1): 1-14.

Franck, P. \& Young, A. (1972). Stock price reaction of multinational firms to exchange realignments. Financial Management, 1 , 66-73

Frankel, J. (1983). Monetary and portfolio balance models of exchange rate determination. MIT Press, Cambridge.

Giovannini, A. \& Jorion, P. (1987). Interest rates and risk premia in the stock market and in the foreign exchange market. Journal of International Money and Finance, 6(1): 107-123.

Granger, C., Huang, B. \& Yang, C. (2000). A bivariate causality between stock prices and exchange rates: evidence from recent Asian flu. The Quarterly Review of Economics and Finance, 40(3): 337-354.

Guris, B. (2017). A new nonlinear unit root test with Fourier function. MPRA Paper 82260, University Library of Munich, Germany.

Habimana, O., Månsson, K. \& Sjölander, P. (2018). Testing for nonlinear unit roots in the presence of a structural break with an application to the qualified PPP during the 1997 Asian financial crisis. International Journal of Finance and Economics, 23(3): 221-232.

Hajilee, M. \& Al-Nasser, O. (2014). Exchange rate volatility and stock market development in emerging economies. Journal of Post Keynesian Economics, 37(1): 163-180.

Hung-Pin, L. (2014). Renewable energy consumption and economic growth in nine OECD countries: bounds test approach and causality analysis. The Scientific World Journal, 2, 919167. http://dx.doi.org/10.1155/2014/919167

Jebran, K. \& Iabal, A. (2016). Dynamics of volatility spill-over between stock market and foreign exchange market: Evidence from Asian countries. Financial Innovation, 2(1): 1-20.

Jorion, P. (1990). The exchange exposure of US multinational firm. Journal of Business, 63, 331-345.

Kang, S. \& Yoon, S. (2013). Revisited return and volatility spill-over effect in Korea. Korea and the World Economy, 14(1): $121-145$

Kapetanios, G., Shin, Y. \& Snell, A. (2003). Testing for a unit root in the nonlinear STAR framework. Journal of Econometrics, 112, 359-379.

Kennedy, K. \& Nourizad, K. (2016). Exchange rate volatility and its effect on stock market volatility. International Journal of Human Capital and Urban Management, 1(1): 37-46. http://dx.doi.org/10.7508/ijhcum.2016.01.005

Khan, R. \& Ali, R. (2015). Causality analysis of volatility in exchange rate and stock market prices: A case study of Pakistan. Asian Economic and Financial Review, 5(5): 805-815.

Lawal, A., Somoye, R. \& Babajide, A. (2016). Impact of oil price shocks and exchange rate volatility on stock market behavior in Nigeria. Binus Business Review, 7(2): 171-177. http://dx.doi.org/10.21512/bbr.v7i2.1453

Leybourne, S., Newbold, P. \& Vougas, D. (1998). Unit roots and smooth transitions. Journal of Time Series Analysis, 19(1): 83-97.

Lo, M. \& Morley, J. (2015). Bayesian analysis of nonlinear exchange rate dynamics and the purchasing power parity persistence puzzle. Journal of International Money and Finance, 51, 285-302.

Ma, C. \& Kao, G. (1990). On Exchange Rate Changes and Stock Price Reactions. Journal of Business Finance and Accounting, $17,441-449$

Maku, O. \& Atanda, A. (2010). Determinants of stock market performance in Nigeria: long-run analysis. Journal of Management and Organizational Behavior, 1(3): 1-16

Moore, T. \& Wang, P. (2014). Dynamic linkage between real exchange rates and stock prices: Evidence from developed and emerging Asian markets. International Review of Economics and Finance, 29, 1-11.

Morley, B. (2006). Causality between economic growth and immigration: An ARDL bounds testing approach. Economics Letters, 90, 72-76. 
Najaf, R. \& Najaf, K. (2016). A Study of Exchange Rates Movement and Stock Market Volatility. Asian Journal of Management, Engineering and Computer Sciences, 1(1): 32-38.

Nkoro, E. \& Uko, A. (2016). Exchange rate and inflation volatility and stock prices volatility: Evidence from Nigeria, 19862012. Journal of Applied Finance and Banking, 6(6): 57-70.

Okpara, G. \& Odionye, J. (2012). The direction of volatility spill-over between stock prices and exchange rate: Evidence from Nigeria. Elixer Finanance, 42, 6410-6414.

Olugbenga, A. (2012). Exchange rate volatility and stock market behavior: The Nigerian experience. European Journal of Business and Management, 4(5): 31-39.

Osamwonyi, I. \& Evbayiro-Osagie, E. (2012). The relationship between macroeconomic variables and stock market index in Nigeria. Journal of Economics, 3(1): 55-63.

Pesaran, M. \& Shin, Y. (1999). An autoregressive distributed lag modeling approach to cointegration analysis. The Ragnar Frisch Centennial Symposium, Chapter 11. Cambridge University Press, Cambridge.

Pesaran, M., Shin, Y. \& Smith, R. (2001). Bounds Testing Approaches to the analysis of level relationships. Journal of Applied Econometrics, 16, 289-326. http://dx.doi.org/10.1017/CCOL0521633230.011

Salisu, A. \& Oloko, T. (2015). Modelling spillovers between stock market and FX market: evidence for Nigeria. Journal of African Business, 16(1-2): 84-108.

Shahbaz, M., Ahmed, N. \& Ali, L. (2008). Stock market development and economic growth: ARDL causality in Pakistan. International Research Journal of Finance and Economics, 14(1): 182-195.

Shin, Y., Yu, B. \& Greenwood-Nimmo, M. (2014). Modelling asymmetric cointegration and dynamic multipliers in a nonlinear ARDL framework. In Festschrift in honor of Peter Schmidt : 281-314. New York: Springer.

Sollis, R. (2004). Asymmetric adjustment and smooth transitions: a combination of some unit root tests. Journal of Time Series Analysis, 25(3): 409-417.

Solnik, B. (1987). Using financial prices to test exchange rate models: A note. The Journal of Finance, 42(1): 141-149.

Tsai, I. (2012). The relationship between stock price index and exchange rate in Asian markets: A quantile regression approach. Journal of International Financial Markets, Institutions and Money, 22(3): 609-621.

Tule, M., Dogo, M. \& Uzonwanne, G. (2018). Volatility of stock market returns and the naira exchange rate. Global Finance Journal, 35, 97-105.

Tursoy, T. (2017). Causality between stock prices and exchange rates in Turkey: Empirical evidence from the ARDL bounds test and a combined cointegration approach. International Journal of Financial Studies, 5(1): 1-10. https://doi.org/10.3390/ijfs5010008

Van-Hoang, T., Lahiani, A. \& Heller, D. (2016). Is gold a hedge against inflation? New evidence from a nonlinear ARDL approach. Economic Modelling, 54, 54-66.

Xiong, Z. \& Han, L. (2015). Volatility spill-over effect between financial markets: evidence since the reform of the RMB exchange rate mechanism. Financial Innovation, 1(1): 1-12. https://doi.org/10.1186/s40854-015-0009-2

Yang, S. P. (2017). Exchange rate dynamics and stock prices in small open economies: Evidence from Asia-Pacific countries. Pacific-Basin Finance Journal, 4, 337-354.

Zhang, L. (2016). Performance of unit-root tests for non-linear unit-root and partial unit-root processes. Communications in Statistics-Theory and Methods, 45(15): 4528-4536.

Zhao, H. (2010). Dynamic relationship between exchange rate and stock price: Evidence from China. Research in International Business and Finance, 24(2): 103-112.

Zivot, E. \& Andrews, D. (1992). Further evidence on the Great Crash, the oil price shock, and the unit-root hypothesis. Journal of Business and Economic Statistics, 10, 251-270.

Zolfaghari, M. \& Sahabi, B. (2016). Impact of foreign exchange rate on oil companies' risk in stock market: A Markov-switching approach. Journal of Computational and Applied Mathematics, 317, 274-289.

Zubair, A. (2013). Causal relationship between stock market index and exchange rate: Evidence from Nigeria. CBN Journal of Applied Statistics, 4(2): 87-110. 
Appendix-I



Source: Central Bank of Nigeria/Nigerian Stock Exchange

Figure 1. Trend of Exchange Rate and All Share Index 
Appendix-II

\begin{tabular}{|c|c|c|c|c|c|c|c|c|}
\hline & \multicolumn{2}{|c|}{ 1999/01-2018/02 } & \multicolumn{2}{|c|}{ 1999/01-2007/12 } & \multicolumn{2}{|c|}{ 2008/01-2018/02 } & \multicolumn{2}{|c|}{ 2014/01-2018/02 } \\
\hline & Coefficient & $p$-value & Coefficient. & $p$-value & Coefficient. & $p$-value & Coefficient. & $p$-value \\
\hline \multicolumn{9}{|c|}{$R E R=f\left(A S I^{+}, A S I^{-}\right)$} \\
\hline & $0.5362^{* *}$ & 0.0001 & $0.2510^{* *}$ & 0.0100 & $0.5831^{* *}$ & 0.0001 & $0.5050^{* *}$ & 0.0003 \\
\hline$\Delta R E R_{t-2}^{-}$ & $-0.2240^{* *}$ & 0.0010 & & & $-0.2510^{* *}$ & 0.0083 & & \\
\hline$\triangle A S I^{+}$ & -0.0139 & 0.7007 & -0.0018 & 0.7265 & -0.0132 & 0.8347 & 0.0345 & 0.4069 \\
\hline$\triangle A S I_{t-1}^{+}$ & $0.0756^{*}$ & 0.0385 & & & $0.1272^{*}$ & 0.0429 & & \\
\hline$\triangle A S I^{-}$ & 0.0581 & 0.1288 & 0.0029 & 0.8054 & 0.0510 & 0.3885 & $-0.0830^{*}$ & 0.0439 \\
\hline$\triangle A S I_{t-1}^{-}$ & $-0.1447^{* *}$ & 0.0002 & & & $-0.2139^{*}$ & 0.0003 & & \\
\hline \multicolumn{9}{|c|}{ Long Run Adjustment Parameters } \\
\hline$E C M$ & -0.0135 & 0.2239 & -0.0089 & 0.6074 & -0.0335 & 0.1081 & $-0.1786^{* *}$ & 0.0057 \\
\hline \multicolumn{9}{|c|}{ Long Run Coefficients } \\
\hline$A S I^{+}$ & -0.3081 & 0.3758 & -0.1959 & 0.8138 & 0.2331 & 0.4739 & 0.1931 & 0.3592 \\
\hline$A S I^{-}$ & -0.6078 & 0.2041 & 0.3283 & 0.8022 & -0.1468 & 0.6431 & $-0.4648^{*}$ & 0.0162 \\
\hline$C$ & $4.7498^{* *}$ & 0.0001 & $5.5463^{* *}$ & 0.0024 & $4.3883^{* *}$ & 0.0001 & $5.0155^{*}$ & 0.0001 \\
\hline
\end{tabular}

Source: Authors' Computation

Note: RER and ASI denote log of Real Exchange Rate and All Share Index respectively; ${ }^{* *}$ and ${ }^{*}$ denote level of significance of $1 \%$, and 5\%, respectively.

Table 4a. NARDL Estimation RER Model 


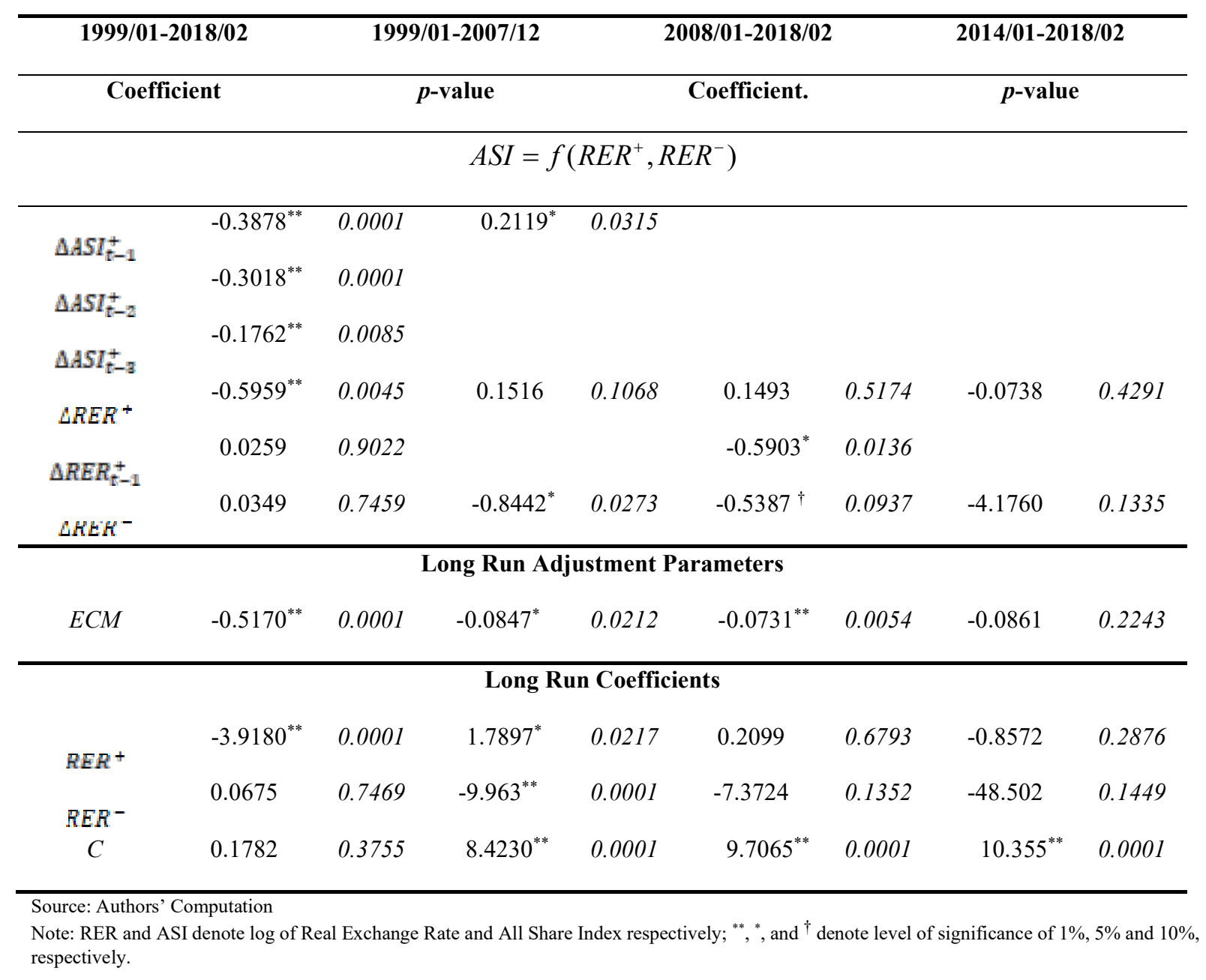

Table 4b. NARDL Estimation ASI Model 


\begin{tabular}{ccccccc}
\hline & \multicolumn{3}{c}{$R E R=f\left(A S I^{+}, A S I^{-}\right)$} & & $A S I=f\left(R E R^{+}, R E R^{-}\right)$ \\
\hline & $R^{2}$ & SR $(\boldsymbol{p}$-value $)$ & ARCH $(\boldsymbol{p}$-value $)$ & $\boldsymbol{R}^{2}$ & SR $(\boldsymbol{p}$-value $)$ & ARCH $(\boldsymbol{p}$-value $)$ \\
\hline $1999 / 01-2018 / 02$ & 0.9943 & $0.2292(0.8760)$ & $26.598(0.0001)$ & 0.9870 & $3.2375(0.0231)$ & $5.0952(0.0020)$ \\
$1999 / 01-2007 / 12$ & 0.9940 & $0.4609(0.7102)$ & $1.8818(0.1376)$ & 0.9940 & $0.4609(0.7102)$ & $1.8818(0.1376)$ \\
$2008 / 01-2018 / 02$ & 0.9902 & $0.2660(0.8498)$ & $14.745(0.0001)$ & 0.9214 & $0.6449(0.5978)$ & $0.7594(0.5192)$ \\
$2014 / 01-2018 / 02$ & 0.9805 & $0.3543(0.7863)$ & $4.7383(0.0063)$ & 0.8826 & $0.4180(0.7410)$ & $0.8743(0.4620)$ \\
\hline
\end{tabular}

Source: Authors' Computation

Note: SR represents serial correlation test; RER and ASI denote log of Real Exchange Rate and All Share Index respectively.

Table 5. Diagnostic Tests 


\begin{tabular}{|c|c|c|c|c|c|c|c|}
\hline & Short Run & Long Run & Strong & & Short Run & Long Run & $\overline{\text { Strong }}$ \\
\hline \multicolumn{4}{|c|}{$H$ : Asymmetric $A S I$ does not cause $R E R$} & \multicolumn{4}{|c|}{$H$ : Asymmetric $R E R$ does not cause $A S I$} \\
\hline \multicolumn{8}{|c|}{$1999 / 01-2018 / 02$} \\
\hline$A S I^{+}$ & & 1.4877 & 1.8990 & $R E R^{+}$ & $4.4470^{*}$ & $3.4427^{\dagger}$ & $4.7001^{*}$ \\
\hline$p$-value & 0.0986 & 0.2226 & 0.1682 & $p$-value & 0.0350 & 0.0635 & 0.0302 \\
\hline \multirow{2}{*}{$\begin{array}{c}\mathrm{ASI}^{-} \\
p \text {-value }\end{array}$} & & 1.4877 & $14.412^{* *}$ & $R E R^{-}$ & 0.7172 & $3.4427^{\dagger}$ & 1.2110 \\
\hline & 0.0003 & 0.2226 & 0.0001 & $p$-value & 0.3971 & 0.0635 & 0.2711 \\
\hline \multicolumn{8}{|c|}{$1999 / 01-2007 / 12$} \\
\hline \multirow{2}{*}{$\begin{array}{c}A S I^{+} \\
p \text {-value }\end{array}$} & 0.1230 & 0.2656 & 0.1229 & $R E R^{+}$ & $2.6473^{\dagger}$ & $5.4780^{*}$ & $3.7668^{*}$ \\
\hline & 0.7258 & 0.6063 & 0.7259 & $p$-value & 0.1037 & 0.0193 & 0.0523 \\
\hline \multirow{2}{*}{$\begin{array}{c}\text { Asi }^{-} \\
p \text {-value }\end{array}$} & 0.0610 & 0.2656 & 0.2540 & KEK ${ }^{-}$ & $5.0137^{*}$ & $5.4760^{*}$ & $4.7958^{*}$ \\
\hline & 0.8049 & 0.6063 & 0.6143 & $p$-value & 0.0251 & 0.0193 & 0.0285 \\
\hline \multicolumn{8}{|c|}{$3 / 02$} \\
\hline \multirow{2}{*}{$\begin{array}{c}A S I^{+} \\
p \text {-value }\end{array}$} & 2.3083 & 2.6247 & 1.2642 & $R E R^{+}$ & $3.4913^{\dagger}$ & $8.0312^{* *}$ & $4.1961^{*}$ \\
\hline & 0.1287 & 0.1052 & 0.2609 & $p$-value & 0.0617 & 0.0046 & 0.0405 \\
\hline \multirow{2}{*}{$\begin{array}{c}A S I^{-} \\
p \text {-value }\end{array}$} & $10.689^{* *}$ & 2.6247 & $13.171^{* *}$ & \multirow{2}{*}{$\begin{array}{c}R E R^{-} \\
p \text {-value }\end{array}$} & $2.8583^{\dagger}$ & $8.0312^{* *}$ & 2.1486 \\
\hline & 0.0011 & 0.1052 & 0.0003 & & 0.0909 & 0.0046 & 0.1427 \\
\hline \multicolumn{8}{|c|}{$2014 / 01-2018 / 02$} \\
\hline \multirow{2}{*}{$\begin{array}{c}A S I^{+} \\
p \text {-value }\end{array}$} & 0.7015 & $8.4617^{* *}$ & $5.8181^{* *}$ & $R E R^{+}$ & 0.6366 & 1.5182 & 0.0318 \\
\hline & 0.4023 & 0.0036 & 0.0159 & $p$-value & 0.4250 & 0.2179 & 0.8586 \\
\hline \multirow{2}{*}{$\begin{array}{c}\mathrm{ASI}^{-} \\
p \text {-value }\end{array}$} & $4.3107^{*}$ & $8.4617^{* *}$ & $3.5882^{*}$ & \multirow{2}{*}{$\begin{array}{c}R E R^{-} \\
p \text {-value }\end{array}$} & 2.3353 & 1.5182 & 2.3088 \\
\hline & 0.0379 & 0.0036 & 0.0582 & & 0.1265 & 0.2179 & 0.1286 \\
\hline
\end{tabular}

Source: Authors' Computation

Note: RER and ASI denote log of Real Exchange Rate and All Share Index respectively; ${ }^{* *},{ }^{*}$, and ${ }^{\dagger}$ denote level of significance of $1 \%, 5 \%$ and $10 \%$, respectively.

Table 6. NARDL Causality Test 